\title{
BEE DRONE BROOD HOMOGENATE CHEMICAL COMPOSITION, STABILIZATION AND APPLICATION: A REVIEW
}

\author{
*Iveta Rutka, Ruta Galoburda, Janis Galins, Ainars Galins \\ Latvia University of Life Sciences and Technologies, Latvia \\ *Corresponding author's email: rutkaiveta@inbox.lv
}

\begin{abstract}
The aim of this study was to review research findings and information about chemical composition and application of bee drone brood homogenate for food purposes. As the world's population grows, global warming and the impact of meat production on the ecosystem are increasingly being discussed. Various non-traditional sources of protein, such as insects and larvae, could replace traditional sources of meat protein in the future. Drone brood homogenate is obtained from honey bee drone larvae and is considered to be a very high value by-product of beekeeping. Scientific studies prove the prophylactic properties of drone brood homogenate to improve fertility and strengthen immunity against viral diseases. This product is rich in nutrients, amino acids, vitamins, minerals and hormones but a certain harvesting and processing technology is required to ensure that the product has a sufficient shelf life and an attractive appearance.
\end{abstract}

Key words: drone larvae, Apilarnil, honeybee products, bee pupae, brood homogenate, drone brood, drone milk.

\section{Introduction}

Honey and other bee products have been known for a very long time. These products are used as food and food supplements to improve health, because honey and other bee products are deemed to be prophylactic (Çelik et al., 2019). Modern beekeeping is inconceivable without the presence of the Varroa mite (Varroa destructor). This parasite is a global problem for beekeepers, as it can lead to the death of a bee colony. Bees collect pollen and pollinate plants. Pollination is necessary for the plants to reproduce. The death of a bee colony affects the reproduction of plants, which is necessary for the maintenance of the ecosystem (Flores et al., 2021). Today, the topical issue is the change in the use of varroasis control products, as Varroa mite in the world have become accustomed to synthetic pesticides, and bee colonies are weakening due to the increasing use of chemicals in agriculture (Kasiotis et al., 2021). Many chemicals are banned in the European Union because they have a negative impact on the ecosystem. Harmful substances must not be allowed to enter beekeeping products. One of the most gentle ways to combat the spread of Varroa mites and other diseases is to remove bee drone larvae from the hive (Charriére et al., 2003). Beekeepers on organic farms use this technique to control Varroa mites, because bee drone cells are attracted by a significantly higher number of mites than working bee cells. The development cycle of bee drone brood is longer than the development of working bees; therefore, Varroa mites develop in drone brood cells, because mites in working bee broods do not reach the maturity necessary for the production of offspring. Bee drone cells are 1.5 times larger in diameter than working bee cells (Yadav, Kumar, \& Jat, 2017). The second reason why bee drone larvae are removed from the hive is to limit the number of drones for working bees. Bee drones eat a significant amount of honey from the hive and cause losses of honey to beekeepers. Thus, bee drone brood homogenate is produced from drone larvae as a byproduct of beekeeping.

Drone brood homogenate $(\mathrm{DBH})$ is one of the bee products also known as Apilarnil discovered by Romanian beekeeper Mr. Nicolae V. Iliesiu. It is a homogeneous milky product with a sour taste, yellowish colour or sometimes a shade of grey (Barnutiu et al., 2013; Sawczuk, Karpinska, \& Miltyk, 2019). The product is obtained by removing bee drone larvae from hives before closing the cells. In many literature sources, this product has been compared with royal jelly (Bogdanov, 2016; Çelik et al., 2019; Sawczuk, Karpinska, \& Miltyk, 2019), which is milky secretion produced by worker honeybees for the purpose of feeding larvae and adult bee queens (Pavel et al., 2011).

Bee drone larvae are rich in nutrients, vitamins and hormones. The aim of this study was to review the research findings and latest information about chemical composition and application of bee drone brood homogenate for food purposes.

\section{Materials and Methods}

The monographic method was used to summarise the research findings and latest information about bee drone brood homogenate for food purposes. Information was searched for in Science Direct, Scopus, Web of Science, Google Scholar. The following keywords were used in the selection of scientific literature: 'drone larvae', 'Apilarnil', 'honeybee products', 'bee pupae', 'drone brood', 'drone milk' and 'brood homogenate'.

\section{Results and Discussion}

\section{Harvesting of bee drone larva}

Bees have different stages of development: egg, larva, pupa and imago (adult stage). Drones, the males 


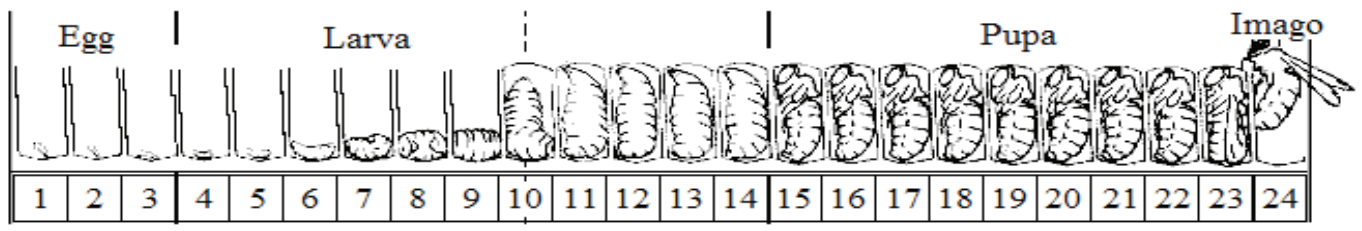

Figure 1. Stages of bee drone development (Modified by the authors, source:

Development of the honey bees, 2021).

of the colony, are produced from unfertilized eggs. The developmental period of drones is 24 days (Yadav, Kumar, \& Jat, 2017). From days 1 to 3, there is an egg (Figure 1). The size of a bee egg is approximately 1.5 $\mathrm{mm}$ (Woyke, 1998). From day 4 to day 14, there is the larva. From day 15 to day 23, there is the pupa. On day 24 , an imago is formed from the pupa. On day 10 , the working bees cap the larval cells of the drones. Bee drone larval harvesting should be planned at a certain stage in the life cycle of the bee drone. Day 10, when the drone cell is capped, it could be used to determine the age of the larva.

The day of the developmental cycle when it is harvested has a significant effect on larval composition. In the Romanian patent No. 0043842 B1 (Iliesiu, 1984), it is mentioned that bee drone larvae should be collected on day 10 of the development cycle. In patent RU No. 2402920 (Луцук, Дьяченко, \& Белик, 2010), the larvae should be 9-10 days old. The stage of larva is characterised by a high nutritive value. The stage of prepupae begins from day 10 to day 14. In Patent US 2014/0323.014 A1, it is mentioned that the external feature of harvesting is when the prepupae are in a vertical position in the capped cells, with colourless or slightly yellowing eyelets without pigmentation (Trifonov et al., 2014). The harvested larvae are then homogenized and filtered. Species, region, climatic conditions and flora are likely to have significant effects (Sawczuk, Karpinska, \& Miltyk, 2019).

Characteristics of drone brood homogenate chemical composition

Scientific studies provide information on protein levels depending on the age of the larvae (Grishina $\&$ Gengin, 2016). There is a tendency that as the age of the larva increases, the ratio of protein to larval mass increases. The trend of increasing protein concentration depending on the stage of development can also be found in other sientific research (Ghosh, Jung, \& Meyer-Rochow, 2016). The working bee's pupa contains more protein than the larva, but the amount of carbohydrates decreases (Table 1).

Characteristics of $\mathrm{DBH}$ are presented in the Table 2, which shows the chemical composition for both fresh and lyophilised DBH and royal jelly. The composition of DBH is similar to royal jelly. Therefore, these products are often compared in research on bee products (Bogdanov, 2016). It is shown that the content of fructose and sucrose DBH is lower than in royal jelly. The chemical composition of $\mathrm{DBH}$ varies in different studies, but is within certain limits.

DBH was defined as a perspective alternative protein source if appropriate production, collection and processing is organized (Ulmer, Smetana, \& Heinz, 2020). Geographical location and climate affect the composition of both royal jelly and larvae. The bee species could also have some effect. There are at least eight honeybee species in the world (Bees4life, 2021). European honeybee (Apis mellifera) is the most common worldwide. This specie is native to Europe, western Asia, and Africa. Proteins supplied in a lyophilised format are more stable for storage purposes. Potential degradation pathways for proteins: hydrolysis; oxidation; racemization; isomerization; denaturation; adsorption. Lyophilised proteins should not be exposed to atmospheric oxygen. Higher level than $\mathrm{pH} 8$ should also be avoided. In pharmacy, it is recommended that lyophilised peptides and proteins should be stored at temperatures $-20^{\circ} \mathrm{C}$ or $-80{ }^{\circ} \mathrm{C}$ to minimize degradation (Manning et al., 2010).

Table 1

Approximate nutrients composition of larva, pupa and imago (adult) development stage, \% of dry matter (Ghosh, Jung, \& Meyer-Rochow, 2016)

\begin{tabular}{|l|l|l|l|}
\hline \multicolumn{1}{|c|}{ Nutrients } & \multicolumn{1}{c|}{ Larva } & \multicolumn{1}{c|}{ Pupa Imago (adult) } \\
\hline Protein & 35.3 & 45.9 & 51 \\
\hline Fat & 14.5 & 16 & 6.9 \\
\hline Carbohydrate & 46.1 & 34.3 & 30.6 \\
\hline Ash & 4.1 & 3.8 & 11.5 \\
\hline
\end{tabular}


Characteristics of fresh and lyophilised drone brood homogenate and royal jelly

Table 2

\begin{tabular}{|c|c|c|c|c|}
\hline \multirow{2}{*}{ Characteristics* } & \multicolumn{2}{|c|}{ Drone brood homogenate } & \multicolumn{2}{c|}{ Royal jelly } \\
\cline { 2 - 5 } & fresh & lyophilised & fresh & lyophilised \\
\hline $\mathrm{pH}$ & $4.80-6.70$ & - & $3.40-4.50$ & - \\
\hline Acidity, $\mathrm{ml} 0.1 \mathrm{~N} \mathrm{NaOH} \mathrm{g}^{-1}$ & $0.88-3.28$ & - & $3.00-6.00$ & - \\
\hline Water, \% & $65.0-76.4$ & $3.0-4.5$ & $60.0-70.0$ & 2.7 \\
\hline Protein, \% & $4.6-12.0$ & $32.0-52.4$ & $9.0-18.0$ & $27.0-41.0$ \\
\hline Lipids, \% & $1.3-8.0$ & $21.1-24.2$ & $3.0-8.0$ & $8.0-19.0$ \\
\hline Carbohydrates, \% & $6.0-12.2$ & $17.8-38.9$ & $7.0-18.0$ & 26.8 \\
\hline Ash, \% & $0.7-2.0$ & $2.7-4.1$ & $0.8-3.0$ & 3.5 \\
\hline Energy value, $\mathrm{kJ} 100 \mathrm{~g} \mathrm{~g}^{-1}$ & 503.3 & $1974.8-2097.9$ & $381 * *$ & 1525.9 \\
\hline
\end{tabular}

'-' - information not found; *Data collected from Barnutiu et al., 2013; Bogdanov, 2016; Isidorov, Bakier, \& Stocki, 2016; Margaoan et al., 2017; Sawczuk, Karpinska, \& Miltyk, 2019; Silici, 2019. **Calculated values.

\section{Comparison of hormone content in prepupae, bee drone brood and royal jelly}

\begin{tabular}{|c|c|c|c|}
\hline $\begin{array}{c}\text { Hormones, } \\
\text { nmol }(100 \mathrm{~g})^{-1}\end{array}$ & $\begin{array}{c}\text { Prepupae with yellowing } \\
\text { eyelets }(10-14 \text { days old)* }\end{array}$ & $\begin{array}{c}\text { Fresh drone brood (9-11 days } \\
\text { old)** }\end{array}$ & Fresh royal jelly** \\
\hline Testosterone & $0.292-0.322$ & $0.310 \pm 0.015$ & $0.200 \pm 0.030$ \\
\hline Progesterone & $42.63-60.01$ & $51.32 \pm 8.69$ & $4.61 \pm 0.26$ \\
\hline Prolactin & $344.60-475.40$ & $410.00 \pm 65.40$ & $70.80 \pm 20.00$ \\
\hline Estradiol (oestradiol) & $431.20-847.90$ & $677.60 \pm 170.30$ & $52.00 \pm 6.00$ \\
\hline
\end{tabular}

*Data obtained from Trifonov et al., 2014; Трифонов et al., 2013; **Data obtained from Bogdanov, 2016.

Bee drone larvae contain much higher concentrations of hormones than royal jelly (Table 3). In Patent US 2014/0323.014 A1 it is mentioned that drone prepupae with yellowing eyelets guarantee hormone concentrations within certain limits (Trifonov et al., 2014).

DBH can be used as a hormone preparation to improve fertility due to the significant hormone concentration of this product. Testosterone is the primary androgen responsible for the development and maintenance of male sexual characteristics. Progesterone is the dominant ovarian hormone with the function to prepare the uterus for embryo implantation. Prolactin stimulates the breasts to produce milk. Estradiol is the dominant ovarian hormone during the follicular (first) phase of the menstrual cycle (BPACNZ, 2013).

Amino acids perform a vital role in the development and maintenance of body. Humans can only synthesize 11 of the 20 important amino acids, which are necessary to make proteins. The other nine essential amino acids are obtained from the diet. Essential amino acids are involved in the biochemical processes of protein synthesis. Amino acid deficiency impairs immune function and increases the susceptibility to diseases (Kubala, 2018; Wu, 2009). Bee drone larvae contain eight of nine essential amino acids: methionine, histidine, threonine, phenylalanine, isoleucine, valine, lysine, and leucine.

The concentration of amino acids in drone larvae is higher than in worker larvae, thus bee drone larvae are a better source of amino acids (Ghosh et al., 2020; Ghosh, Jung, \& Meyer-Rochow, 2016).

Drone brood homogenate is a rich source of vitamins. Vitamins are necessary for the normal growth, development and functioning of the body (Yaman et al., 2021). The vitamin content is influenced by the diversity of plants used by bees to feed larvae and produce honey (Silici, 2019). DBH contains large amounts of water-soluble B vitamins, such as thiamine (B1), riboflavin (B2), niacin (B3), pantothenic acids (B5), pyridoxine (B6), biotin (B7), folic acid (B9), and cobalamin (B12) (Kistanova et al., 2020; Silici, 2019). Vitamin $C$ and choline are also found in $\mathrm{DBH}$ (Finke, 2005).

Important minerals in $\mathrm{DBH}$ are potassium $(\mathrm{K})$, sodium $(\mathrm{Na})$, calcium $(\mathrm{Ca})$, magnesium $(\mathrm{Mg})$ (Özkök, \& Erdem, 2017). A study by Narumi (2004) found 
zinc $(\mathrm{Zn})$, iron $(\mathrm{Fe})$, phosphorus $(\mathrm{P})$, manganese $(\mathrm{Mn})$, copper $(\mathrm{Cu})$ and large amounts of selenium $(\mathrm{Se})$ in honeybee brood. Selenium has not been found in other studies. This can be explained by the fact that selenium comes from the soil. Selenium is taken up from the ground by plants, which are pollinated by bees, so that selenium enters bee products (Li et al., 2017; Zhao et al., 2005).

Application of drone brood homogenate

Due to the chemical composition of bee drone larval homogenate, this product is widely used in veterinary medicine (Kistanova et al., 2020; Shoinbayeva et al., 2017), but few studies on the effects on human health have been found (Sidor, \& Dżugan, 2020). DBH is also discussed in apitherapy (Çelik et al., 2019). Scientific studies prove the prophylactic properties of $\mathrm{DBH}$ to improve fertility and strengthen immunity against viral diseases.

Improving semen quality of stud rams (male sheeps). Adding the preparation of $\mathrm{DBH}$ in the dosages of $15 \mathrm{mg} \mathrm{kg}^{-1}$ of live body weight once per day increased the volume of ejaculate to $30.4 \%$, concentration of spermatozoa in the ejaculate up to $14.3 \%$, mobility of spermatozoa increases to 9.2 points (Shoinbayeva et al., 2017).

Improving fertility of female pigs. Gilts feed supplementation with the DBH promotes folliculogenesis in the ovaries of gilts at morphological and gene expression level (Kistanova et al., 2020).

Stimulation of genital development. The raw DBH increased the relative organ weights of the glans penis, seminal vesicle and levator ani muscle in rats. It also increased the average prostate weight. The raw DBH was able to increase the relative organ weight of the uteri inimmature female rats (Seres et al., 2013).

The use of DBH for feeding male broilers (Yucel et al., 2011) did not result in a significant increase in total body weight, but improving laying efficiency of hens was detected (Muravev \& Kalachinskaya, 2014).

Immunity improvement to prevent viral diseases. Consumption of $\mathrm{DBH}$ with vitamin $\mathrm{D}_{3}$ significantly increased the body's immunity to viral diseases. The patients received 1 tablet of the preparation 2 times a day during a three-month course.

Methods for drone brood homogenate stabilisation

Table 4

\begin{tabular}{|c|c|c|c|}
\hline Method & $\begin{array}{l}\text { Short description of processing } \\
\text { parameters }\end{array}$ & $\begin{array}{l}\text { Effect on product quality during its } \\
\text { storage }\end{array}$ & References \\
\hline \multirow[t]{2}{*}{ Freezing } & Brood in the combs, at $-20^{\circ} \mathrm{C}$ & $\begin{array}{l}\text { Without severe change of taste can } \\
\text { be stored for } 6 \text { months }\end{array}$ & Jensen et al., 2019 \\
\hline & $\begin{array}{c}\text { Cleaned brood in vacuum-sealed } \\
\text { bags, at }-20{ }^{\circ} \mathrm{C}\end{array}$ & $\begin{array}{l}\text { Without severe change of taste can } \\
\text { be stored for } 10 \text { months }\end{array}$ & Jensen et al., 2019 \\
\hline \multirow[t]{2}{*}{$\begin{array}{l}\text { Freeze drying } \\
\text { (lyophilisation) }\end{array}$} & $\begin{array}{c}\text { The lyophilised powder was prepared } \\
\text { by freeze drying to the temperature } \\
\text { of }-5^{\circ} \mathrm{C} \text {, under residual pressure of } \\
0.03 \mathrm{mmHg} \text { for } 24 \mathrm{~h}\end{array}$ & $\begin{array}{c}\text { The product retained the original } \\
\text { biological properties }\end{array}$ & $\begin{array}{c}\text { Shoinbayeva et al., } \\
2017\end{array}$ \\
\hline & $\begin{array}{l}\text { The freezing is done rapidly in } \\
\text { temperatures of }-50{ }^{\circ} \mathrm{C} \text { and }-80^{\circ} \mathrm{C} \text {, } \\
\text { primary drying at pressure of a few } \\
\text { millibars, secondary drying can even } \\
\text { be above } 0{ }^{\circ} \mathrm{C}\end{array}$ & $\begin{array}{l}\text { Lyophilised DBH obtained moisture } \\
\text { content of } 1 \% \text { to } 4 \% \text { and retained the } \\
\text { original biological properties }\end{array}$ & $\begin{array}{c}\text { Berk, 2013; } \\
\text { Bogdanov, } 2016\end{array}$ \\
\hline \multirow[t]{3}{*}{$\begin{array}{l}\text { Mixing with } \\
\text { honey or } \\
\text { sugars }\end{array}$} & $\begin{array}{l}\text { Mixed with honey (not more than } \\
1-2 \% \text { of brood) }\end{array}$ & $\begin{array}{l}\text { Mixtures can be stored for } 6 \text { months } \\
\text { at room temperature }\end{array}$ & $\begin{array}{l}\text { Bogdanov, 2016; } \\
\text { Бурмистрова et al., } \\
2008\end{array}$ \\
\hline & $\begin{array}{l}\text { Adsorption on glucose-lactose }(1: 1) \\
\text { and dried until } 4 \% \text { moisture content }\end{array}$ & $\begin{array}{c}\text { Can be stored at } 4-6^{\circ} \mathrm{C} \text { up to } 2 \\
\text { years }\end{array}$ & $\begin{array}{c}\text { Bogdanov, 2016; } \\
\text { Бурмистрова et al., } \\
2008\end{array}$ \\
\hline & $\begin{array}{l}\text { Mixed with lactose and glucose, then } \\
\text { drying is performed with IR-rays } \\
\text { during } 4 \text { hours at } 42-45^{\circ} \mathrm{C} \text { in the } \\
\text { "heating-cooling" pulse mode }\end{array}$ & $\begin{array}{l}\text { Moisture content decrease and } \\
\text { biologically active substances } \\
\text { preservation, reduction of } \\
\text { microbiological contamination and } \\
\text { decay prevention }\end{array}$ & $\begin{array}{l}\text { Чекрыга, Волончук, } \\
\quad \& \text { Левин, } 2012\end{array}$ \\
\hline Adding ethanol & $\begin{array}{l}\text { DBH combined with } 40 \% \text { and } 70 \% \\
\text { ethyl alcohol with added antioxidant }\end{array}$ & $\begin{array}{c}\text { Obtained stable tincture which has } \\
\text { an extended shelf life and retains its } \\
\text { biological activity of the components } \\
\text { for } 2 \text { years }\end{array}$ & $\begin{array}{l}\text { Будникова, 2011; } \\
\text { Гашим et al., } 2018\end{array}$ \\
\hline
\end{tabular}


There were no cases of acute respiratory disease or influenza in the patients during the autumn and winter period (Strukov et al., 2016).

Processing and preservation of drone brood

Drone larvae should be harvested together with the combs. Removal from the hive should be done carefully so as not to injure the larvae. Both open and capped larvae will stay alive at room temperature for a few hours after removal from hive (Jensen et al., 2019). Other studies suggest that larvae should be refrigerated immediately after cutting out from the combs. Freezing, drying, boiling or frying should be completed less than 24 hours after collection of larvae to avoid any spoilage. Insect proteins decay much faster than those of beef, pork, lamb or chicken (Bogdanov, 2011; Krell, 1996). Rapid larval deterioration may begin after homogenisation, thus DBH requires immediate processing under strict hygiene requirements. One of the solutions used by beekeepers is to freeze $\mathrm{DBH}$ at $-20{ }^{\circ} \mathrm{C}$ or mix it with honey in certain proportions (Hroshovyi et al., 2021; Isidorov, Bakier, \& Stocki, 2016). Sugar helps to prevent or slow down the growth of bacteria, moulds and yeast in food (SNRC, 2021). Honey, sucrose, lactose or glucose can be used as preservatives (Митрофанов et al., 2015). Different stabilization technologies can be used to efficiently extend the shelf life of DBH (Table 4).

Freeze drying is a process in which water is removed from a product after it is frozen and placed under a vacuum, allowing the ice to change directly from solid to vapour without passing through a liquid phase (FDA, 2014). The absence of water prevents microbial growth and chemical changes leading to deterioration of product. Lyophilised DBH kept the original biological properties, measured by its immunomodulating, spleen and T-cell stimulating properties (Bogdanov, 2016). Freeze drying did not reduce DBH hormone levels (Sidor \& Dżugan, 2020). The maximum allowable drying temperature must not exceed $45^{\circ} \mathrm{C}$, as this will inactivate the hormones and biological activity in the product (Будникова, 2011; Корж, 2009). Freeze drying could be the most suitable drying technology for DBH to improve the shelf life of the product. Spray drying could also be used, but elevated temperatures can degrade product quality the product loses hormones and vitamins.
Most of the consumers avoid eating insects, larvae or worms, which could be one of the alternative sources of protein in the future (Higa et al., 2020). Encapsulated DBH would be more attractive and convenient for consumers.

$\mathrm{DBH}$ is a product rich in nutrients, minerals and hormones, and its effective use is possible through certain harvesting and processing technologies. The shelf life can be extended by freezing and drying, and additives can be added. The processing technology used must not impair the valuable composition of the product. The resulting product must be acceptable and safe for the consumers. In the future, $\mathrm{DBH}$ could be widely produced as a food supplement in Latvia as well, but extensive research is needed on the processing and chemical composition of $\mathrm{DBH}$ obtained in the Baltic region and its impact on human health and safety.

\section{Conclusions}

Drone brood homogenate $(\mathrm{DBH})$ is considered to be a very high value by-product of beekeeping, which can bring additional income to beekeepers if it is properly processed. Geographical location, climate, species and stage of development affect both the composition of the royal jelly and the larvae. Bees feed drone larvae with royal jelly, but DBH is made from drone larvae, so the composition of these two beekeeping products is similar, but $\mathrm{DBH}$ has elevated levels of sex hormones. In order for $\mathrm{DBH}$ to obtain the highest hormone concentration, the collection of drone larvae should be performed on days 10 to 14 of the developmental stage, observing the external feature: the prepupae in a vertical position in the capped cells, with colourless or slightly yellowing eyelets without pigmentation. Scientific studies show that the use of DBH has health benefits, including improved fertility of animals, strengthening immunity to prevent viral diseases. DBH is a product rich in nutrients, amino acids, vitamins, minerals and hormones but a certain harvesting and processing technology is required to ensure that the product has a sufficient shelf life and an attractive appearance. DBH was defined as a perspective alternative protein source, which could replace pork or beef in the future.

\section{References}

Barnutiu, L.I., Marghitaş, L.A., Dezmirean, D., Bobiş, O., Mihai, C., \& Pavel, C. (2013). Physico-chemical composition of apilarnil (bee drone larvae). Lucrări Ştiinţifice-Seria Zootehnie, 59, 199-202.

Bees4life. (2021). Honey Bee Species. Retrieved February 20, 2021, from https://bees4life.org/blog/curiousbee-life/8-honey-bee-species.

Berk, Z. (2013). Freeze drying (lyophilization) and freeze concentration. In Z. Berk (Ed.) Food Process Engineering and Technology (pp. 567-581). Academic Press. DOI: 10.1016/b978-0-12-415923-5.00023-x. Bogdanov, S. (2011). Royal jelly, bee brood: composition, health, medicine: a review. Lipids, 3(8), 8-19. 
Bogdanov, S. (2016). Chapter 2. Royal jelly, bee brood: Composition, nutrition, health. In The Royal Jelly Book. Retrieved February 20, 2021, from https:/www.bee-hexagon.net/english/bee-products/downloadsroyal-jelly-book/.

BPACNZ. (2013). Reproductive hormones. Retrieved February 21, 2021, from https://bpac.org.nz/BT/2013/ February/02_hormones.aspx.

Çelik, K., Demir, E., Baytekin, H., Yilmaz, M., Krol, B., Palkova, Z., ... Özcan, A. (2019). Apitherapy handbook. Ankara: Sonçağ Akademi Yayinlari.

Charriére, J.D., Imdorf, A., Bachofen, B., \& Tschan, A. (2003). The removal of capped drone brood: An effective means of reducing the infestation of varroa in honey bee colonies. Bee World, 84(3), 117-124. DOI: $10.1080 / 0005772 X .2003 .11099587$.

Development of the honey bees. (2021). Retrieved February 20, 2021, from http:/www.bee-info.com/biologybee/development-tabular.html.

FDA. (2014). Lyophilization of Parenteral. Retrieved February 20, 2021, from https:/www.fda.gov/inspectionscompliance-enforcement-and-criminal-investigations/inspection-guides/lyophilization-parenteral-793.

Finke, M.D. (2005). Nutrient composition of bee brood and its potential as human food. Ecol. Food Nutr. 44(4), 257-270. DOI: 10.1080/03670240500187278.

Flores, J.M., Gámiz, V., Jiménez-Marín, Á., Flores-Cortés, A., Gil-Lebrero, S., Garrido, J.J., \& Hernando, M.D. (2021). Impact of Varroa destructor and associated pathologies on the colony collapse disorder affecting honey bees. Res. Vet. Sci. 135, 85-95. DOI: 10.1016/j.rvsc.2021.01.001.

Ghosh, S., Jung, C., \& Meyer-Rochow, V.B. (2016). Nutritional value and chemical composition of larvae, pupae, and adults of worker honey bee, Apis mellifera ligustica as a sustainable food source. J. Asia-Pac. Entomol. 19(2), 487-495. DOI: 10.1016/j.aspen.2016.03.008.

Ghosh, S., Sohn, H.Y., Pyo, S.J., Jensen, A.B., Meyer-Rochow, V.B., \& Jung C. (2020). Nutritional composition of Apis mellifera drones from Korea and Denmark as a potential sustainable alternative food source: Comparison between developmental stages. Foods, 9(4). DOI: 10.3390/foods9040389.

Grishina, Z., \& Gengin, M. (2016). Changes in peptide and protein concentrations during the ontogenesis of honeybee (A. mellifera) drone larvae is associated to variations in protease activity, Biotecnol. Apl. 33(4), 4221-4224.

Higa, J.E.E., Ruby, M.B.B., \& Rozin, P. (2020). Americans' acceptance of black soldier fly larvae as food for themselves, their dogs, and farmed animals. Food Qual. Prefer. 90, 104-119. DOI: 10.1016/j. foodqual.2020.104119.

Hroshovyi, T., Dobrynchuk, M., Pavliuk, B., \& Chubka, M. (2021). Drone brood - as a raw material for the manufacture of medicines and dietary supplements. Sci. Europe 63, 36-39.

Iliesiu, N. (1984). Patent RO No. 0043842 B1. Courier Press, Leamington Spa, England, European Patent Office.

Isidorov, V.A., Bakier, S., \& Stocki, M. (2016). GC-MS investigation of the chemical composition of honeybee drone and queen larva homogenate. J. Apic. Sci. 60(1), 111-120. DOI: 10.1515/JAS-2016-0011.

Jensen, A.B., Evans, J., Jonas-Levi, A., Benjamin, O., Martinez, I., Dahle, B., ... Foley, K. (2019). Standard methods for Apis mellifera brood as human food. J. Apicult. Res. 58(2), 1-28. DOI: 10.1080/00218839.2016.1226606.

Kasiotis, K.M., Zafeiraki, E., Kapaxidi, E., Manea-Karga, E., Antonatos, S., Anastasiadou, P., ... Machera, K. (2021). Pesticides residues and metabolites in honeybees: A Greek overview exploring Varroa and Nosema potential synergies. Sci. Total Environ. 769, 145-213. DOI: 10.1016/j.scitotenv.2021.145213.

Kistanova, E., Zdoroveva, E., Nevitov, M., Nosov, A., Vysokikh, M., Sukhanova, I., ... Boryaev, G. (2020). Drone brood fed supplement impacts on the folliculogenesis in growing gilts. Vet. Arhiv 90(6), 583-592. DOI: 10.24099/vet.arhiv.0886.

Krell, R. (1996). Value-added products from beekeeping. Roma: FAO Food and Agriculture Organization of the United Nations.

Kubala, J. (2018). Essential Amino Acids: Definition, Benefits and Food Sources. Retrieved February 20, 2021, from https://www.healthline.com/nutrition/essential-amino-acids.

Li, Z., Liang, D., Peng, Q., Cui, Z., Huang, J., \& Lin, Z. (2017). Interaction between selenium and soil organic matter and its impact on soil selenium bioavailability: A review. Geoderma 295, 69-79. DOI: 10.1016/j. geoderma.2017.02.019.

Manning, M.C., Chou, D.K., Murphy, B.M., Payne, R.W., \& Katayama, D.S. (2010). Stability of protein pharmaceuticals: An update. Pharm. Res. 27(4), 544-575. DOI: 10.1007/s11095-009-0045-6. 
Margaoan, R., Marghitas, L.A., Dezmirean, D.S., Bobos, O., Bonta, V., Catana, C., ... Margin, M.G. (2017). Comparative Study on Quality Parameters of Royal Jelly, Apilarnil and Queen Bee Larvae Triturate. Bulletin of University of Agricultural Sciences and Veterinary Medicine Cluj-Napoca. Animal Sci. Biotechnol. 74(1), 51. DOI: 10.15835/buasvmcn-asb:12622.

Muravev, D., \& Kalachinskaya, A. (2014). Drone homogenate and laying hens productivity. Vestnik of Kazan State Agrarian University 9(1), 130-134.

Narumi, S. (2004). Honeybee brood as a nutritional food. Honeybee Science - Tamagawa University (Japan) $25,119-124$.

Özkök, A., \& Erdem, B. (2017). Can food supplement produced from apilarnil be an alternative to testosterone replacement therapy. Hacet. J. Biol. Chem. 4(45), 635-638. DOI: 10.15671/hjbc.2018.207.

Pavel, C.I., Mărghitaş, L.A., Bobiş, O., Dezmirean, D.S., Şapcaliu, A., Radoi, I., \& Mădaş, M.N. (2011). Biological Activities of Royal Jelly - Review. Sci. P. Animal Sci. Biotechnol. 44(2), 108-118.

Sawczuk, R., Karpinska, J., \& Miltyk, W. (2019). What do we need to know about drone brood homogenate and what is known. J. Ethnopharmacol. 245, 111-581. DOI: 10.1016/j.jep.2018.10.042.

Seres, A., Ducza, E., Bathori, M., Hunyadi, A., Beni, Z., Dekany, M., \& Gaspar, R. (2013). Raw drone milk of honeybees elicits uterotrophic effect in rats: Evidence for estrogenic activity. J. Med. Food 16(5), 404-409. DOI: 10.1089/jmf.2012.0232.

Shoinbayeva, K.B., Omirzak, T., Bigara, T., Abubakirova, A., \& Dauylbay, A. (2017). Biologically active preparation and reproductive function of stud rams. Asian J. Pharm. 11(3), 184-191.

Sidor, E., \& Dżugan, M. (2020). Drone brood homogenate as natural remedy for treating health care problem: a scientific and practical approach. Molecules 25(23). DOI: 10.3390/molecules25235699.

Silici, S. (2019). Chemical content and bioactive properties of drone larvae (Apilarnil). Mellifera 19(2), 14-22.

SNRC. (2021). Functions of sugars in food and drinks. Retrieved February 25, 2021, from https://www. sugarnutritionresource.org/the-basics/functions-of-sugars-in-food.

Strukov, V.I., Prokhorov, M.D., Jones-Strukova, O., \& Trifonov, V.N. (2016). Patent Application Publication. Pub. No.: US 2016 / 0271610 A1.

Trifonov, V.N., Elistratova, J.A., Elistratov, K.G., \& Kurus, N.V. (2014). Patent Application Publication. Pub. No.: US 2014/0323.014 A1. United States, Patent Application Publication.

Ulmer, M., Smetana, S., \& Heinz, V. (2020). Utilizing honeybee drone brood as a protein source for food products: Life cycle assessment of apiculture in Germany. Res. Con. Rec. 154, 104-576. DOI: 10.1016/j. resconrec.2019.104576.

Woyke, J. (1998). Size change of Apis mellifera eggs during the incubation period. J. Apicul. Res. 37(4), 239246. DOI: 10.1080/00218839.1998.11100978.

Wu, G. (2009). Amino acids: Metabolism, functions, and nutrition. Amino Acids 37(1), 1-17. DOI: 10.1007/ s00726-009-0269-0.

Yadav, S., Kumar, Y., \& Jat, B.L. (2017). Honeybee: Diversity, castes and life cycle. In Omkar (Ed.) Industrial Entomology. Singapore: Springer. DOI: 10.1007/978-981-10-3304-9.

Yaman, M., Çatak, J., Uğur, H., Gürbüz, M., Belli, İ., Tanyıldız, S.N., .. Yaldı, M.C. (2021). The bioaccessibility of water-soluble vitamins: A review. Trends Food Sci. Tech. 109, 552-563. DOI: 10.1016/j.tifs.2021.01.056.

Yucel, B., Acikgoz, Z., Bayraktar, H., \& Seremet, C. (2011). The effects of apilarnil (drone bee larvae) administration on growth performance and secondary sex characteristics of male broilers. J. Anim. Vet. Adv. 10(17), 2263-2266. DOI: 10.3923/javaa.2011.2263.2266.

Zhao, C., Ren, J., Xue, C., \& Lin, E. (2005). Study on the relationship between soil selenium and plant selenium uptake. Plant Soil 277(1-2), 197-206. DOI: 10.1007/s11104-005-7011-9.

Будникова, Н.В. (2011). Совершенствование технологии производства и хранения трутневого расплода медоносных пчел (Improvement of production and storage of drone brood of honey bees. Unpublished doctoral dissertation). Государственное научное учреждение научно-исследовательский иститут пчеловодства Россйской академии сельскохозяйственных наук, Рыбное, Россия. (in Russian).

Бурмистрова, Л.А., Агафонов, А.В., Будникова, Н.В., \& Харитонова, М.Н. (2008). Способы стабилизации биологически активных компонентов маточного молочка (Methods for the stabilisation of biologically active components of royal jelly). In Апитерапия сегодня (сборник 13) Материалы XIII Всероссийской научно-практической конференции “Успехи апитерапии” (Apitherapy Today (vol. 13) Proceedings of the XIII Russian scientific-practical conference "Success in apitherapy"), 11-13 October, 2007 (pp. 175182). Adler, Russia: Russian Academy of Agricultural Science. (in Russian).

Гашим, М.С., Васильевич, П.В., Алексеевна, К.В., Петровна, Р.Е., Константинович, Р.Б., Александровна, Б.Л., \& Валентиновна, Б.Н. (2018). Patent RU No. 2690516 C2. Россия, Федеральная служба по интеллектуальной собственности. 
Корж, В. (2009). Здоровье дарит нам пчела (Bees give us health). Харьков: ООО «ЭДЭНА». (in Russian).

Луцук, С., Дьяченко, Ю., \& Белик, Ю. (2010). Patent RU No. 2402920. Россия, Федеральная служба по интеллектуальной собственности, патентам и товарным знакам.

Митрофанов, Д.В., Бурмистрова, Л.А., Будникова, Н.В., Есенкина, С.Н., \& Степанцева, Г.К. (2015). Стабилизация биологически активных компонентов трутневого расплода адсорбцией (Stabilization of biologically active components of drone brood by adsorption). Сборник научно-исследовательских работ по пчеловодству, 170-175. (in Russian).

Трифонов, В.Н., Елистратова, Ю.А., Елистратов, К.Г., Курусь, Н.В., Хомякова, И.В., Елистратова, T.В., \& Будникова, Н.В. (2013). Patent RU No. 2011153905 А. Россия, Федеральная служба по интеллектуальной собственности.

Чекрыга, Г.П., Волончук, С.К., \& Левин, В.С. (2012). Patent RU No. 2523885 C1. Россия, Федеральная служба по интеллектуальной собственности. 